\title{
The Grey Areas Between Open and Closed in Innovation Networks
}

\author{
Seppo Leminen, Taija Turunen, and Mika Westerlund
}

\author{
"Become dangerously open to all points of view." \\ Are you dangerously open, or safely closed? \\ Bryant McGill \\ In Simple Reminders: Inspiration for Living Your \\ Best Life
}

\begin{abstract}
This study argues that there are different degrees of openness and closedness in innovation activity, and it highlights the need for more research on the "grey areas" between totally open and totally closed innovation, particularly in innovation networks where multiple stakeholders collaborate for innovation. Here, we focus on four key aspects of innovation networks, as characterized by their degrees of openness or closedness: governance, motivation, interaction, and innovation practices. The categorization is based on a review of theory and an empirical analysis of three distinct innovation networks, two of which represent the open living lab model, and one of which exemplifies the traditional closed innovation model. Our results can help managers improve efficiency in innovation networks by better understanding the grey areas between open and closed in innovation.
\end{abstract}

\section{Introduction}

Innovation is increasingly perceived as collaboration beyond company boundaries rather than intra-organizational action (Berchicci, 2013). Consequently, involving customers and users as co-developers of innovation has become a trend in many industries. Despite the obvious benefits of developing new products and services that better serve market needs, there are several challenges. Ideas from customers and users are often considered more radical, original, and valuable, but ideas from in-house developers are often more realizable (Edvardsson et al., 2010). Moreover, innovation drawing on external sources calls for open structures and processes.

Today's intense competition and short lifecycles require faster development of products and services (Duhamel et al., 1995). Many innovators find it difficult and costly to gain sufficient understanding of customers. Thus, companies no longer attempt to grasp the details of user needs alone, but operate through innovation networks characterized by openness and collaboration as well as heterogeneous actors (Ed- vardsson et al., 2012; Leek \& Canning, 2011). In particular, they reassign the design aspect of innovation development to users who can help with the innovation and create new ideas (Edvardsson et al., 2010; de Vries, 2006).

The living labs model (Budweg et al., 2011; Dell'Era \& Landoni, 2014; Leminen, 2015; Leminen \& Westerlund, 2012; Nyström et al., 2014; Westerlund \& Leminen, 2011) is a particularly interesting form of multi-actor collaboration. In living labs, stakeholders form public-private-people partnerships of firms, public agencies, universities, and users all collaborating to create, prototype, validate, and test new technologies, services, products, and systems in real-life contexts (Leminen et al., 2012). Despite the growing popularity of living labs that are essentially open innovation networks but that can also utilize characteristics associated with closed innovation such as selective or restricted participation, there is scant research on the "grey areas" between open and closed innovation in living labs (Leminen \& Westerlund, 2013).

Hence, previous research presents open and closed innovation as distinct alternatives (Almirall \& Casadeus- 


\title{
The Grey Areas Between Open and Closed in Innovation Networks
}

\author{
Seppo Leminen, Taija Turunen, and Mika Westerlund
}

Masanell, 2010; Leminen \& Westerlund, 2011). The open innovation literature discusses innovation activities that involve customers, users, and other stakeholders, whereas closed innovation refers to innovation activities that come about within a single organization. Kviselius and colleagues (2012) call for more research on the characteristics of these two modes. We aim to understand the grey areas between open and closed in innovation networks, whereas the main body of existing research focused on either totally open or totally closed innovation. To achieve these objectives, we focus on the following research questions:

- What are the characteristics of open and closed innovation networks?

- How do the grey areas between open and closed innovation show up in innovation networks?

The article is structured as follows. First, we review the theoretical foundations of open and closed innovation, and we present living labs as a form of open innovation network. Then, we describe our research methodology and provide empirical findings on the grey areas between open and closed innovation in innovation networks. Finally, we discuss our findings, comment on the managerial challenges, and offer practical recommendations.

\section{Theoretical Background}

People today live in a world of networks that redefine their lifestyles. It is becoming a challenge to develop offerings that meet hyper-differentiated consumer demands (Arakji \& Lang, 2007). Many firms no longer attempt to grasp the details of consumer needs alone, but reassign product development to external sources of ideas, such as customers and users, who can help generate ideas and create new innovations and value (Edvardsson et al., 2010). Although the idea about "prosumers" (producer-customers) is not new (Dahlander et al., 2008) only recent research has underlined the prolific role of users as innovators (cf. Bogers et al., 2010; Leminen et al., 2015).

Customer insight speeds up the development processes and lowers costs, because it is otherwise expensive to try to understand user needs. Zaltmann (2003) argues that at least 80 per cent of new products and services fail when launching them into market. Thus, integrating customers and users into innovation development as co-developers is increasingly popular. Co-development is about co-opting the competences of customers and bringing users into the innovation and design processes (Edvardsson et al., 2010). This approach enables a firm to understand users' actual behaviours, needs, and future trends, but it requires openness in processes and structures.

Although firms draw on their own expertise to access markets, openness refers to the pooling of knowledge for innovative purposes, where the contributors have access to the inputs of others and cannot exert exclusive rights over the innovation (Chesbrough \& Appleyard, 2007). Value created through an open process approaches that of a public good and causes fear of losing intellectual property rights. According to Cassiman and Valentini (2009), firms should simultaneously consider the type of research and development $(\mathrm{R} \& \mathrm{D})$ to be performed and the organization of $R \& D$ that includes the exposure of the project to knowledge from outside the firm.

Dahlander and Gann (2010) discuss forms of openness via pecuniary and non-pecuniary benefits, and via inbound and outbound innovation. Respectively, pecuniary and non-pecuniary refer to direct and indirect benefits to the firm. Inbound innovation refers to the internal use of external knowledge and outbound innovation refers to external exploitation of internal knowledge (Huizingh, 2011). Open innovation assumes that openness is a strategic choice of a firm to use external and internal ideas and their paths to market (Chesbrough 2003). Laursen and Salter (2006) introduced "external search breadth" and "external search depth" to characterize a firm's strategy to acquire external knowledge to exploit innovative opportunities. Almirall and CasadeusMasanell (2010) found "discovery" and "divergence" effects related to open innovation.

Openness is evident in innovation networks. BergvallKåreborn and Ståhlbröst (2009) consider openness as an "iterative process cycle" in a network. Pisano and Verganti (2008) discuss networks through the choice of "governance" (hierarchical or flat) and "participation" (open or closed). Westerlund and Leminen (2011) suggest that the "degree of openness" and networking increase when a firm advances towards user-driven innovation. Schweisfurth, Raasch, and Herstatt (2011) put forward five characteristics of openness, and Huizingh (2011) describes innovation types with the help of innovation process and innovation outcome. Finally, Drechsler and Natter (2012) argue that openness is a manager's key strategic decision. Table 1 summarizes previous research that helps us identify the characteristics of openness in innovation networks. 


\section{The Grey Areas Between Open and Closed in Innovation Networks}

\section{Seppo Leminen, Taija Turunen, and Mika Westerlund}

Table 1. Openness and closedness in innovation networks

\begin{tabular}{|c|c|c|c|}
\hline Construct & Characteristics of Construct & Definition of Construct & Sources \\
\hline \multirow[t]{2}{*}{$\begin{array}{l}\text { Open and closed } \\
\text { innovation }\end{array}$} & $\begin{array}{l}\text { Open and closed innovation } \\
\text { paradigms }\end{array}$ & $\begin{array}{l}\text { Openness as choice of using } \\
\text { external or internal ideas and } \\
\text { their paths to market }\end{array}$ & Chesbrough (2003) \\
\hline & Discovery and divergence & $\begin{array}{l}\text { Open innovation allows } \\
\text { discovery of new product } \\
\text { landscapes }\end{array}$ & $\begin{array}{l}\text { Almirall \& Casadesus- } \\
\text { Masanell (2010) }\end{array}$ \\
\hline \multirow[t]{4}{*}{ Openness } & External search breadth and depth & $\begin{array}{l}\text { Openness as individual firm's } \\
\text { external search strategies and } \\
\text { external performance }\end{array}$ & Laursen \& Salter (2006) \\
\hline & $\begin{array}{l}\text { Pecuniary and non-pecuniary benefits; } \\
\text { inbound and outbound innovation }\end{array}$ & $\begin{array}{l}\text { Openness as inbound and } \\
\text { outbound processes }\end{array}$ & Dahlander \& Gann (2010) \\
\hline & $\begin{array}{l}\text { Innovation process (open or closed) } \\
\text { and innovation outcome (open or } \\
\text { closed) }\end{array}$ & $\begin{array}{l}\text { Openness as a taxonomy of } \\
\text { innovation processes and } \\
\text { outcomes }\end{array}$ & Huizingh (2011) \\
\hline & $\begin{array}{l}\text { Iterative process cycle (generate needs, } \\
\text { design, and evaluate) }\end{array}$ & $\begin{array}{l}\text { Openness as a process with } \\
\text { stakeholders }\end{array}$ & $\begin{array}{l}\text { Bergvall-Kåreborn \& } \\
\text { Ståhlbröst (2009) }\end{array}$ \\
\hline $\begin{array}{l}\text { Open and closed } \\
\text { network }\end{array}$ & $\begin{array}{l}\text { Governance (hierarchical or flat) and } \\
\text { participation (open or closed) }\end{array}$ & $\begin{array}{l}\text { Openness as a choice of } \\
\text { governance and participation } \\
\text { in collaboration networks }\end{array}$ & Pisano \& Verganti (2008) \\
\hline \multirow[t]{2}{*}{ Degree of openness } & $\begin{array}{l}\text { Degree of openness (open or closed) } \\
\text { and type of co-creation (producer-led } \\
\text { or customer-led) }\end{array}$ & $\begin{array}{l}\text { Openness as a stepwise model } \\
\text { for a company becoming an } \\
\text { open innovation company }\end{array}$ & $\begin{array}{l}\text { Westerlund \& Leminen } \\
(2011)\end{array}$ \\
\hline & $\begin{array}{l}\text { Firms innovation strategy, scarce firm } \\
\text { resources, appropriability regime, and } \\
\text { market dynamics }\end{array}$ & $\begin{array}{l}\text { Openness as a usage of } \\
\text { external information in } \\
\text { innovation }\end{array}$ & Drechsler \& Natter (2012) \\
\hline $\begin{array}{l}\text { Openness, open } \\
\text { innovation }\end{array}$ & $\begin{array}{l}\text { Types of actors, motivation, } \\
\text { contractual framework (transparency, } \\
\text { accessibility, and IP contribution), } \\
\text { decision right, and innovation process } \\
\text { (phases) }\end{array}$ & $\begin{array}{l}\text { Openness as a taxonomy of } \\
\text { five characteristics }\end{array}$ & Schweisfurth et al. (2011) \\
\hline
\end{tabular}

\section{Framework}

We focus on the characteristics of openness (cf. Pisano \& Verganti, 2008; Schweisfurth et al., 2011; Westerlund \& Leminen, 2011) to comprehend openness and closedness in networks. We deem that innovation networks comprise different types of actors; Leminen, Westerlund, and Nyström (2012) identified these actors in living labs as utilizers, enablers, providers, or users. Figure 1 illustrates our framework and its four key characteristics of openness or closedness in innovation networks: governance, motivation, interaction, and innovation practices.

\section{Governance}

Pisano and Verganti (2008) propose a two-by-two matrix to distinguish between diverse innovation networks. They demonstrate governance to be one of the key elements of networks. Mulder, Velthausz, and Kriens, (2008) identify governance as one of six perspectives to 


\title{
The Grey Areas Between Open and Closed in Innovation Networks
}

\author{
Seppo Leminen, Taija Turunen, and Mika Westerlund
}

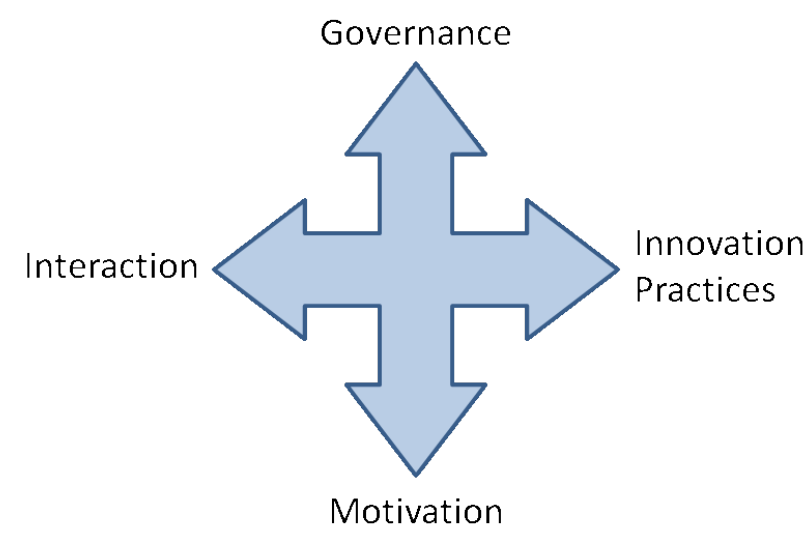

Figure 1. Framework for analyzing openness and closedness in innovation networks

influence open innovation networks, and Chiaroni Chiesa, and Frattini (2010) address networks crucial for firms to move from a closed innovation mode to open innovation. Schweisfurth, Raasch, and Herstatt (2011) propose that allocation of decision-making rights, such as task definition, task allocation, and selection of result, differ across open innovation procedures. Leminen, Westerlund, and Nyström (2012) argue that the actor making decisions on goal setting varies between different open innovation networks.

Prior literature assumes that networks differ by their management structure, density, and connectivity. Lay and Moore (2009) argue that "collaborative networks" are complex, focus on innovation, and are coordinated by "hubs", whereas "coordinated networks" aim at high volumes and efficiency, and are coordinated by a "concentrator". Centralized networks are good for simple problems; coordination and decentralized networks are suited to complex problems (Lazer \& Friedman, 2007). Chesbrough (2003) emphasizes the management of internal and external ideas when targeting new markets and Von Hippel (2007) shows that open innovation networks are self-coordinated and aim to solve problems of interest to their stakeholders.

\section{Interaction}

Interaction between companies and those beyond organizational boundaries is essential in innovation networks (Pisano \& Verganti, 2008). The literature views open innovation as a process with predefined phases that address collective innovation, user innovation networks, commons-based peer production, crowdsourcing, and open source innovation (Schweisfurth et al., 2011) and living labs (Gong et al., 2012; Kang, 2012;
Lin et al., 2012). In living labs, phases are often documented from an adaptor's perspective on innovation (Bendavid \& Cassivi, 2012), detailed descriptions of execution in living activities (Gong et al., 2012), parts of new product development and commercialization processes (Katzy et al., 2012; Katzy, 2012), and evidence of systemic thinking (van der Waltand \& Buitendag, 2009). Predefined phases may not exist, given that innovation activities are continually redirected based on interaction with users in innovation networks (Westerlund \& Leminen, 2011).

The level of interaction is important. Sjödin, Eriksson, and Frishammar (2011) found that, although the level of interaction in terms of collaboration intensity varies across stages from closed to open modes of innovation, early collaboration paves the way for collaboration in later stages. The open innovation literature (Bogers et al., 2010; von Hippel, 2007) describes different innovation approaches; for example, user-driven innovation is based on tight interaction with users, whereas usercentric innovation assumes looser interaction. The users' roles in networks, such as co-creator, co-developer, tester, or informant, describe the depth of interaction (Leminen et al., 2014).

\section{Innovation practices}

Innovation practices in networks address foundational aspects, such as the transparency of innovation development, accessibility to innovation processes, and intellectual property (IP) issues. Transparency refers to an actor's right to inspect a design and to observe its development in the network, and accessibility refers to a network member's right to participate in the development process by making modifications to previous solutions or contributing new solutions. IP management needs to attend to public commons or the retention of IP rights by a single actor in the form of patents (Schweisfurth et al., 2011).

IP portfolios constitute an important driver of open innovation (Lichtenthaler, 2010). According to Drechsler and Natter (2012), the degree of openness can range from closed to multiple levels of openness, and firms pursuing open innovation may be concerned about ineffective IP protection. IP commons in open innovation draw on copyleft thinking, which concerns the extent of the IP that can be released while enabling initiators to benefit from the innovation (Rajala et al., 2012). By actively acquiring, commercializing, and out-licensing IP in the markets, open innovation contrasts closed innovation processes (Lichtenthaler, 2010). 


\title{
The Grey Areas Between Open and Closed in Innovation Networks
}

\author{
Seppo Leminen, Taija Turunen, and Mika Westerlund
}

\begin{abstract}
Motivation
Motivations to participate are elemental, because being motivated means being compelled or encouraged to act (Battistella \& Nonino, 2012). Actors' motivations can be differentiated by the degree of motivation and their reasons to participate. Schweisfurth, Raasch, and Herstatt (2011) argue that motivation in innovation networks comprises both individual and organizational motives, and they categorize motivations by financial, technological, and socio-political dimensions.
\end{abstract}

The distinction between different types of motivations builds on attitudes, intentions, and goals that lead a participant to act, think, and behave in a certain way (Battistella \& Nonino, 2012). We draw on the classification of intrinsic and extrinsic motivations (Battistella \& Nonino, 2013; Ryan \& Deci, 2000). Network actors are motivated by intrinsic factors, for example, the perceptions of being part of the community and having a social identity, but they also influence the development of neighbourhood (Leminen \& Westerlund, 2012). Extrinsic motivations concern all actions that lead, directly or indirectly, to economic advantages for the contributor. The reward incentives include monetary rewards (Antikainen et al., 2010), free products (Ståhlbröst \& Bergvall-Kåreborn, 2011), and sharing of intellectual property rights (Battistella \& Nonino, 2012).

\section{Research Design}

We apply a multiple case study design (cf. Yin, 2009) to analyze the grey areas between open and closed innovation in three innovation networks. We chose two living lab cases to represent openness and one conventional innovation network that uses a closed approach. The empirical research was based on inductive methods and compounds sources of evidence: interviews with key actors and other actors when necessary, internal documentation, and workshop participation. We used secondary data such as annual reports and marketing material for data triangulation (Diefenbach, 2009).

The cases were chosen because their approaches to innovation development enabled us to explore the grey areas between open and closed innovation. We used the following criteria for case selection: i) they represented innovation networks, ii) multiple actors were engaged in the development of innovation, and iii) innovation took place in real or simulated every-day life with users. We also utilized researcher participation for observation, but due to large network sizes and limited time and resources, were unable to interview every actor in each innovation network. Thus, we focused on the core actors.
From 2008 to 2011, we conducted 53 semi-structured interviews with managers from 10 organizations as well as 9 users. The informants included CEOs, CTOs, sales directors, researchers, project managers, project coordinators, and users. Interviews were carried out through face-to-face meetings and by phone, and they were audio-recorded for transcription and analysis. We cannot reveal the identities and organizations of the informants due to confidentiality reasons, but our findings describe the goals, activities, and outcomes of each network.

\section{Data analysis}

The unit of analysis was an actor's perception of openness. We first mapped the driving actor in each case in accordance with Leminen, Westerlund, and Nyström (2012). Next, we identified user roles following the categorization by Leminen and colleagues (2014). Then, we analyzed the interaction to understand how innovation activities are organized in networks, and we investigated the cases from the perspectives of innovation practice (Schweisfurth et al., 2011) and motivation (Ryan \& Deci, 2000).

We coded the transcribed interviews using themebased coding, in which relevant quotes were placed under each theme in our framework (i.e., governance, motivation, interaction, and innovation practices). By doing so, we followed Roberts (1997) and Neuendorf (2002) in making meaning out of the cases using content analysis and coding. Finally, we summarized the results and interpreted the characteristics in terms of openness and closedness. The outcomes were compared, discussed, and agreed upon by all authors. Table 2 synthesizes the phases of our data analysis process.

\section{Description of Case Networks}

Both Case 1 and Case 2 are living labs dominated by open idea generation. The living lab network represented by Case 1 focuses on prototyping of ideas for the retail industry. It is driven by a regional development organization and includes firms providing technological and methodological solutions, universities, users (e.g., students, employees, residents) and a firm utilizing the results. The living lab network represented by Case 2 develops mobile augmented-reality services with occupants from a particular geographic area and other users (e.g., students). It is driven by a firm utilizing the results, which provides tangible and intangible expertise for other stakeholders (e.g., universities) in the network. 


\section{The Grey Areas Between Open and Closed in Innovation Networks}

\section{Seppo Leminen, Taija Turunen, and Mika Westerlund}

Table 2. Data analysis process used in this study

\begin{tabular}{|c|c|c|}
\hline 1. Open coding & $\begin{array}{l}\text { - Organize cases } \\
\text { - Identify actors in each case }\end{array}$ & - Overview of innovation networks \\
\hline 2. Focused coding & $\begin{array}{l}\text { - Identify driving actors in each case } \\
\text { network } \\
\text { - Identify user roles each case network } \\
\text { - Describe innovation mechanism and } \\
\text { governance of innovation networks }\end{array}$ & $\begin{array}{l}\text { - Map of formerly identified driving } \\
\text { actors (cf. Leminen et al., 2012) } \\
\text { - } \begin{array}{l}\text { Determination of prior identified user } \\
\text { roles (Leminen et al., 2014) }\end{array} \\
\text { - } \quad \text { Detecting innovation mechanisms }\end{array}$ \\
\hline
\end{tabular}

\section{Identifying innovation} dynamics in networks
- Analyze interaction

- Identify innovation practices and motivations

- Compare data to theory
- Detection of interaction across networks

- Map of formerly identified characteristics (cf. Schweisfurth et al., 2011) and motivations (cf. Ryan \& Deci, 2000) in innovation
4. Theorizing based on codes
- Synthesize three previous phases

- Characteristics of openness in innovation networks
Case 3 is characterized by closed innovation. The network is formed around a building infrastructure where players have their own agendas and goals regarding innovation. The dominant player is closest to the customer and therefore can acquire customer information and take over the market. It has access to customer knowledge (e.g., user preferences) and can involve customers in innovation processes for designing the usability of a building. The suppliers are used to bring incremental innovations to the completion of a project.

Next, we analyzed the cases in relation to the framework to illustrate how these networks are governed, how the decisions are made, which way the interaction occurs, what kind of innovation practices these networks employ, and what the essential motivations are.

\section{Findings}

The following subsections reveal the characteristics of openness and closedness in the three investigated innovation networks. Two of the networks are living labs perceived as open innovation networks (Case 1 and Case 2), whereas Case 3 is perceived as a closed innovation network. Table 3 summarizes the innovation mechanisms in our cases.

\section{Governance}

The openness of innovation is related to the type and degree of governance (i.e., structure) in the network. There were flat hierarchical structures driven by an enabler in Case 1 (the regional development organization) and a utilizer in Case 2 (the mobile device manufacturer). They set the overall goals. The outcomes kept forming based on ongoing actions.

"We wanted to know about the purchasing behaviour of different customers in the daily consumer goods trade and understand how to improve their shopping experience through online services." (Case 2, User expert)

"We had the [living lab's] goals, which were approved by the enabler. They kept changing, which is vital in the [living lab] concept - who sets the goals, how do we reach them, and what is the most important goal? [...] If the participants trust each other, we can get good results, organize [the living lab] better, and point out everyone's responsibilities and strengths [...] and share the workload accordingly." (Case 2, Project manager)

In addition to the mutual goal, each actor had their own objectives, for example, seeking business references, developing a prototype, or validating existing 


\section{The Grey Areas Between Open and Closed in Innovation Networks}

\section{Seppo Leminen, Taija Turunen, and Mika Westerlund}

Table 3. Summary of the three innovation network cases

\begin{tabular}{|c|c|c|c|}
\hline & $\begin{array}{l}\text { Case 1: } \\
\text { Dominated by open idea } \\
\text { generation and prototyping }\end{array}$ & $\begin{array}{l}\text { Case 2: } \\
\text { Dominated by open idea } \\
\text { generation }\end{array}$ & $\begin{array}{l}\text { Case 3: } \\
\text { Individual innovations }\end{array}$ \\
\hline Objective & $\begin{array}{l}\text { Develop and test services as a } \\
\text { pilot in the retail industry; } \\
\text { develop prototypes and concepts } \\
\text { within the electronic and mobile } \\
\text { business together with users }\end{array}$ & $\begin{array}{l}\text { Develop augmented-reality } \\
\text { services for a new mobile gadget } \\
\text { in cooperation with users }\end{array}$ & $\begin{array}{l}\text { Build new housing infrastructure } \\
\text { (project-based business) }\end{array}$ \\
\hline $\begin{array}{l}\text { Dominator of } \\
\text { Innovation } \\
\text { Network }\end{array}$ & $\begin{array}{l}\text { Enabler, regional development } \\
\text { organization }\end{array}$ & Utilizer, company & $\begin{array}{l}\text { Organization closest to the } \\
\text { customer interface having the } \\
\text { investment capacity (utilizer) }\end{array}$ \\
\hline Actors & $\begin{array}{l}\text { Enabler (regional development } \\
\text { organization), provider } \\
\text { (universities, ICT companies), } \\
\text { users, and utilizer (retailer) }\end{array}$ & $\begin{array}{l}\text { Enabler, provider (universities, } \\
\text { ICT companies), user, and utilizer } \\
\text { (mobile company) }\end{array}$ & $\begin{array}{l}\text { Provider (investor), utilizer } \\
\text { (builder), user }\end{array}$ \\
\hline User Roles & Co-creator, co-developer & Co-creator, co-developer & Co-creator, informant \\
\hline $\begin{array}{l}\text { Innovation } \\
\text { Outcome }\end{array}$ & $\begin{array}{l}\text { Incremental innovation; } \\
\text { prototypes and concepts co- } \\
\text { developed with users from a } \\
\text { geographical area, students, and } \\
\text { researchers }\end{array}$ & $\begin{array}{l}\text { Radical innovation; mobile } \\
\text { augmented-reality services; } \\
\text { utilizer co-developed innovation } \\
\text { with occupants from a } \\
\text { geographical area, researchers, } \\
\text { and students }\end{array}$ & $\begin{array}{l}\text { Incremental innovation for } \\
\text { usability of buildings (interior } \\
\text { design solutions, lighting } \\
\text { solutions, air ventilation systems) }\end{array}$ \\
\hline
\end{tabular}

concepts. The flat hierarchical structures enabled collaborative processes, the transition of knowledge between the actors, and common learning process. They were major outcomes besides the prototypes, concepts, and services.

In Case 3, the network structure was hierarchical, and each player had their predefined roles. Each network actor had defined the desired outcome before the launch of the project. Case 3 was dominated by a hierarchical setting in the beginning of the project. However, this changed later when interaction increased dramatically as actors started to collectively search for innovative means to complete the project.

"It seems like the end user is not [participating] in any way yet... will not get their voice out or we don't even think about it." (Case 3, Manager)
The decision rights were held by the actor that had the investment capacity. Thus, the utilizer was responsible for steering the network by setting the targets and timescale for the project, but the hierarchical structure flattened in time as each member was allowed to reach their target by any means.

\section{Interaction and innovation practices}

The living lab networks in Case 1 and Case 2 were characterized by flexible interaction between the actors. They relied on technology when agreeing on innovation sessions, preparing material for the sessions, or sharing results from the previous sessions. Sessions encompassed face-to-face interaction. Actors participated actively in innovation and were encouraged to contribute new solutions. Sessions stressed solving upcoming challenges in the network, as well as sharing knowledge. In Case 1, network actors provided project-re- 


\title{
The Grey Areas Between Open and Closed in Innovation Networks
}

\author{
Seppo Leminen, Taija Turunen, and Mika Westerlund
}

lated knowledge to new entrants when an initial player exited, thus ensuring the continuation of the project.

"We first brainstormed and participants generated service ideas for [Company A]... But then, we took a step backwards [...] to reach the objective; i.e., to understand daily consumer goods buying processes, their context, and perceived challenges..." (Case 1, Living lab expert)

"When we emphasize co-creation, [users] will plan the characteristics, options, and delivery of the service together with us [...] but when we become usercentered, user input [information and suggestions] is filtered by our R\&D team and tested with the users [...] We no longer take users into the innovation development as peers." (Case 2, Project Manager)

The previous excerpts illustrate that openness and closedness varied during the innovation. Accordingly, intellectual property rights (IPR) were discussed before the start of the living lab projects, but they did not become an issue because all participants had the right to use the outcomes of the study. However, it was deemed a good idea to keep track of participants' contributions in case such issues would be raised at a later stage.

"We should [know] who's participating and who contributes what. Although it's open innovation, IPR are a big question and there may be legal issues later if it's unclear who did what [in the innovation]. We need tools that can provide some kind of control of access and monitoring of participant contributions." (Case 2, Director)

An example of challenges was the design of carbon prototypes of gadgets when the actual prototypes were still on a product line. The flexible interaction in Case 2 enabled the project to proceed in a different way than originally planned.

"The original plan didn't make sense. It's better to make people more committed and not just show prototypes during a focus group interview but study [people's use experiences] in their daily life contexts." (Case 2, Project manager)

Users' roles cannot be underestimated, because users were equal co-creators of innovation rather than objects of research and observation. In Case 1, they kept shopping diaries and analyzed their shopping behaviour. In Case 2, users participated in the planning of focus group sessions, technology demonstrations and user experience field studies, attended relevant events, and co-analyzed the results.

Case 3 was dominated by a hierarchical setting in the beginning of the project. This changed after the launch of the project, when interaction increased dramatically as actors started to collectively search for innovative means to complete the project.

"We don't have any conflicts of interest (in the network)... but, from my point of view, the biggest challenge is the lack of conceptualization... so that each (network participant) would understand." (Case 3, Manager)

Although in Case 3 the initial phases were undertaken in offices, the project completion took place at the construction site where actors could share ideas and discuss the project's realization. Surprises were unavoidable and the plans could change because of the conditions at the site (e.g., humidity, temperature, light). Actors had to solve problems that were unknown in the early phase.

"We have a hierarchy in place... well, we have certain people who take ownership... those are the utility managers... they are taking care of the whole... if we encounter any unforeseen problems we contact the network partners." (Case 3, Manager)

\section{Motivation}

Case 1 and Case 2 required intrinsic and extrinsic motivation. External rewards (e.g., token gifts, course marks, or formal recognition) were not key motivators, but the users' desire to develop their competences, living areas, or products and services were more prominent. The actors shared the overall motivation and enthusiasm to develop new prototypes, products, and services in both cases, which resulted in incremental innovation in Case 1 and radical innovation in Case 2. In addition, each participant had their individual motives.

"[Overall, participants] need to be motivated and there have to be those who are 110 percent committed." (Case 1, Project Manager)

"The most important motivations were course credits [counted towards my university degree] and the employment certificate, but I also liked the small, unexpected token gifts from the partner companies once the project was finished." (Case 1, User 1) 


\section{The Grey Areas Between Open and Closed in Innovation Networks}

\section{Seppo Leminen, Taija Turunen, and Mika Westerlund}

"Recognition [of our participation came] in the final speech, a box of chocolates, and an USB memory stick... but the most important prize from participation was the experience that I gained." (Case 1, User 2)

Case 3 highlighted extrinsic rewards as motivators. The task had predefined goals that needed to be fulfilled. However, as the process went on, the actors started to transfer ideas and practical tips on the site, which resulted in incremental innovations throughout the project. This process reflects the motivational factors related to the community: being a part of a group and being capable of transferring ideas seem to foster innovation.
Innovation activity had also negative effects. Some innovations conflicted with the initial design, which resulted in unpredicted challenges (e.g., problems arose in air ventilation systems because the lighting was installed in a different way from the initial plan). In Case 3 , the innovation process should probably have followed either the closed or the open model throughout the process. The combination of these two processes resulted in conflicts between the initial design (target) and the process (deployment). Table 4 summarizes the findings from our cases.

Table 4. Findings from the three cases

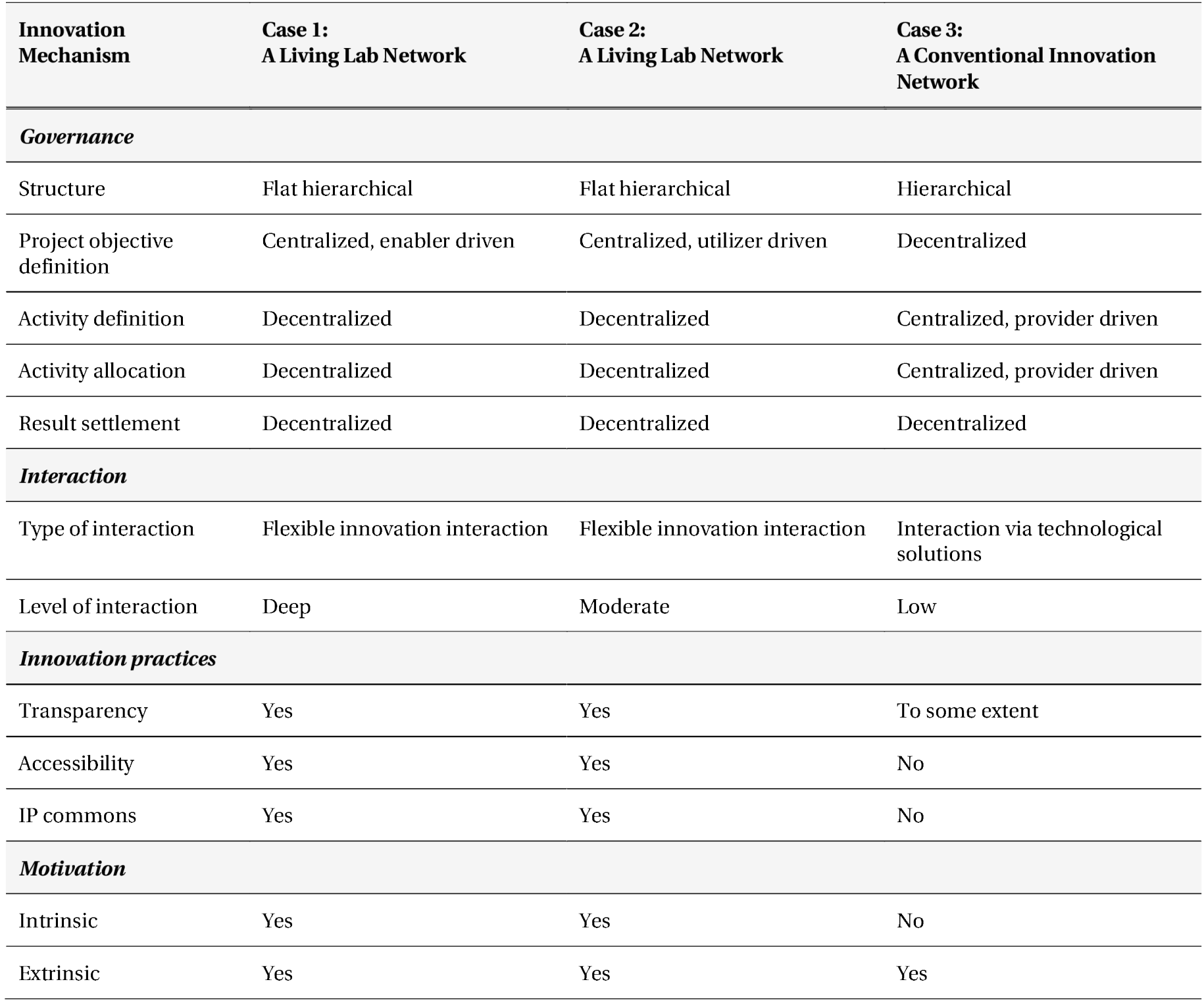




\title{
The Grey Areas Between Open and Closed in Innovation Networks
}

\author{
Seppo Leminen, Taija Turunen, and Mika Westerlund
}

\section{Summary of the cross-case analysis}

Our cases represented opposite innovation models: the living lab networks represented by Case 1 and Case 2 characterized open idea generation and Case 3 represented a conventional project-based business network. Case 1 and Case 2showed that there should not be predefined outcomes, but that a project is a vehicle for discovering and validating unexplored areas. The conventional network (Case 3) had predefined goals, but interaction generated fresh ideas and inventions whose value were not fully understood nor deployed.

Openness increases the degree of freedom. Governance and decision making in the living lab networks represented by Case 1 and Case 2 were decentralized as compared to centralized decision making in the conventional network represented by Case 3 . The modes of governance were selected based on intended outcome and the way of working. We argue that this may reflect the underlying assumptions or development stage of the industries when working with the users and customers (cf. Westerlund \& Leminen, 2011).

Hierarchies, processes or methods do not limit possibilities. Rather, they helped actors to find unconventional solutions to problems in the living lab networks represented by Case 1 and Case 2. In the conventional network represented by Case 3 , all the deviations dealt with the agreed procedures. The representatives of the utilizer informed the firm's steering group of the changes but it did not affect the project level. The living lab networks represented by Case 1 and Case 2 reflected flexible interaction, whereas the conventional network represented by Case 3 showed more structured interaction. This interaction ranged from co-development and co-creation to more formalized activities such as observation and surveys.

Transparency, accessibility, and intellectual property (IP) commons were open in the living lab networks represented by Case 1 and Case 2, but were closed in the conventional network represented by Case 3 . Transparency and accessibility are by definition open when applying open innovation and controlled in conventional projects with closed innovation, in which only some of the participants have full rights to participate in activities. Case 1 and Case 2 showed evidence of both intrinsic and extrinsic motivations, and the conventional network represented by Case 3 relied only on extrinsic motivation.

\section{Conclusions}

Our analysis suggests that there are different degrees of openness and closedness in innovation networks. These "grey areas" between total openness and total closedness are evident when multiple stakeholders pursue the co-development of innovation in networks. We identified four key characteristics of openness:

1. Governance (structure and decision making rights)

2. Motivation (intrinsic and extrinsic)

3. Interaction (type of interaction and level of interaction with users)

4. Innovation practices (transparency, accessibility, and IP commons)

Our findings bring new knowledge on the grey areas of open and closed innovation. The key characteristics of openness can be applied to innovation networks to better understand their operation and management. Our findings also highlight the importance of interaction, which supports the view of Dutilleul Birrer, and Mensink (2010), who suggest that the focus in open processes should be on the analysis of obstructions rather than on processes. We found that interaction varies by the degree of openness and depends on the driving party in the network.

This study contributes to the innovation management literature by showing that the grey areas between total openness and total closedness are affected by various elements:

1. Driving party in the network: who leads the innovation activity?

2. Decision: when should the innovation be open or closed?

3. Interaction: how does the interaction take place within the network actors?

4. Role: what are the different roles of users and stakeholders in innovation networks?

Managers contemplating innovation development need to reframe their innovation practices based on the 


\section{The Grey Areas Between Open and Closed in Innovation Networks}

\section{Seppo Leminen, Taija Turunen, and Mika Westerlund}

characteristics of open networks, especially considering the interaction, not the process. Understanding the grey areas between open and closed innovation in innovation networks helps managers to set up an efficient innovation management process. Although innovation in networks is increasingly popular, the extant literature lacks knowledge of grey areas between the ideal open and closed modes. This gap provides many opportunities for further research.

\section{Acknowledgements}

An earlier version of this paper was presented at the Cambridge Academic Design Management Conference (CADMC), Cambridge, UK, 4-5 September, 2013.

\section{About the Authors}

Seppo Leminen holds positions as Principal Lecturer at the Laurea University of Applied Sciences and Adjunct Professor in the School of Business at Aalto University in Finland. He holds a doctoral degree in Marketing from the Hanken School of Economics and a doctoral degree in Industrial Engineering and management in the School of Science at Aalto University. His research and consulting interests include living labs, open innovation, value co-creation and capture with users, relationships, services and business models in marketing, particularly in Internet of Things (IoT), as well as management models in hightech and service-intensive industries. Results from his research have been reported in Industrial Marketing Management, the Journal of Technology and Engineering and Management, Management Decision, the International Journal of Technology Management, the International Journal of Technology Marketing, the International Journal of Product Development, and the Technology Innovation Management Review, among many others.

Taija Turunen is an Assistant Professor in the Department of Management Studies at Aalto University's School of Business in Finland. Taija holds a doctoral degree in Industrial Engineering and Management from Aalto University's School of Science. During her academic career, Taija has managed several research projects in the area of service operations management and service innovation. Before joining academia, Taija worked as a management consultant in the field of industrial service operations.

Mika Westerlund, DSc (Econ), is an Associate Professor at Carleton University in Ottawa, Canada. He previously held positions as a Postdoctoral Scholar in the Haas School of Business at the University of California Berkeley and in the School of Economics at Aalto University in Helsinki, Finland. Mika earned his doctoral degree in Marketing from the Helsinki School of Economics in Finland. His current research interests include open and user innovation, the Internet of Things, business strategy, and management models in high-tech and service-intensive industries. 


\section{The Grey Areas Between Open and Closed in Innovation Networks}

\section{Seppo Leminen, Taija Turunen, and Mika Westerlund}

\section{References}

Almirall, E., \& Casadesus-Masanell, R. 2010. Open Versus Closed Innovation: A Model of Discovery and Divergence. Academy of Management Review, 35(1): 27-47.

http://dx.doi.org/10.5465/amr.2010.45577790

Antikainen, M., Mäkipää, M., \& Ahonen, M. 2010. Motivating and Supporting Collaboration in Open Innovation. European Journal of Innovation Management, 13(1): 100-119. http://dx.doi.org/10.1108/14601061011013258

Arakji, R. Y., \& Lang, K.R. 2007. Digital Consumer Networks and Producer-Consumer Collaboration: Innovation and Product Development in the Video Game Industry. Journal of Management Information Systems, 24(2): 195-219.

http://dx.doi.org/10.2753/MIS0742-1222240208

Battistella, C., \& Nonino, F. 2012. Open Innovation Web-Based Platforms: The Impact of Different Forms of Motivation on Collaboration. Innovation: Management, Policy \& Practice, 14(4): 557-575.

Battistella, C., \& Nonino, F. 2013. Exploring the Impact of Motivations on the Attraction of Innovation Roles in Open Innovation WebBased Platforms. Production Planning \& Control, 24(2-3): 226-245. http://dx.doi.org/10.1080/09537287.2011.647876

Bendavid, Y., \& Cassivi, L. 2012. A 'Living Laboratory’ Environment for Exploring Innovative RFID -enabled Supply Chain Management Models. International Journal of Product Development, 17(1/2): 23-42.

http://dx.doi.org/10.1504/IJPD.2012.051150

Berchicci, L. 2013. Towards an Open R\&D System: Internal R\&D Investment, External Knowledge Acquisition and Innovative Performance. Research Policy, 42: 117-127. http://dx.doi.org/10.1016/j.respol.2012.04.017

Bergvall-Kåreborn, B., \& Ståhlbröst, A. 2009. Living Lab: An Open and Citizen-Centric Approach for Innovation. International Journal of Innovation and Regional Development, 1(4): 356-370. http://dx.doi.org/10.1504/IJIRD.2009.022727

Baumeister, R. F., \& Leary, M. R. 1995. The Need to Belong: Desire for Interpersonal Attachments as a Fundamental Human Motivation. Psychological Bulletin, 117(3): 497-529.

http://dx.doi.org/10.1037/0033-2909.117.3.497

Bogers, M., Afuah, A., \& Bastian, B. 2010. Users as Innovators: A Review, Critique, and Future Research Directions. Journal of Management, 36(4): 857-875.

http://dx.doi.org/10.1177/0149206309353944

Budweg, S., Schaffers, H., Ruland, R., Kristensen, K., \& Prinz, W. 2011. Enhancing Collaboration in Communities of Professionals Using a Living Lab Approach. Production Planning \& Control, 22(5-6): 594-609.

http://dx.doi.org/10.1080/09537287.2010.536630

Cassiman, B., \& Valentini, G. 2009. Strategic Organization of R\&D: The Choice of Basicness and Openness. Strategic Organization, 7(1): 43-73. http://dx.doi.org/10.1177/1476127008100129

Chiaroni, D., Chiesa, V., \& Frattini, F. 2010. Unravelling the Process from Closed to Open Innovation: Evidence from Mature, AssetIntensive Industries. $R \& D$ Management, 40(3): 222-245. http://dx.doi.org/10.1111/j.1467-9310.2010.00589.x
Chesbrough, H. 2003. The Era of Open Innovation. MIT Sloan Management Review, 44(3): 35-41.

Chesbrough, H., \& Appleyard, M. M. 2007. Open Innovation and Strategy, California Management Review, 50(1): 57-76. http://dx.doi.org/10.2307/41166416

Dahlander, L., \& Gann, D. 2010. How Open Is Innovation? Research Policy, 39: 699-709. http://dx.doi.org/10.1016/j.respol.2010.01.013

Dahlander, L., Frederiksen, L., \& Rullani, F. 2008. Online Communities and Open Innovation: Governance and Symbolic Value Creation. Industry \& Innovation, 15(2): 115-123. http://dx.doi.org/10.1080/13662710801970076

Dell'Era, C., \& Landoni, P. 2014. Living Lab: A Methodology between User-Centred Design and Participatory Design. Creativity and Innovation Management, 23(2): 37-154. http://dx.doi.org/10.1111/caim.12061

Diefenbach, T. 2009. Are Case Studies More Than Sophisticated Storytelling? Methodological Problems of Qualitative Empirical Research Mainly Based on Semi-Structured Interviews. Quality and Quantity, 43: 875-894.

http://dx.doi.org/10.1007/s11135-008-9164-0

Drechsler, W., \& Natter, M. 2012. Understanding a Firm’s Openness Decisions in Innovation. Journal of Business Research, 65: 438-445. http://dx.doi.org/10.1016/j.jbusres.2011.11.003

Dutilleul, B., Birrer, F., \& Mensink, W. 2010. Unpacking European Living Labs: Analysing Innovation's Social Dimensions. Central European Journal of Public Policy, 4(1): 60-85.

Edvardsson, B., Kristensson, P., Magnusson, P., \& Sundström, E. 2012. Customer Integration within Service Development-A Review of Methods and an Analysis of Insitu and Exsitu Contributions. Technovation, 32: 419-429. http://dx.doi.org/10.1016/j.technovation.2011.04.006

Edvarsson, B., Gustafsson, A., Kristensson, P., \& Witell, L. 2010. Service Innovation and Customer Co-Development. In P. Maglio, C. Kielieszewski, \& J. Spohrer (Eds.), Handbook of Service Science. New York: Springer, 561-577.

Gong, G., Hsiao, M., Hsieh, M.-D., Liu, L., Chiu, T., Lin, L.-C., Chen, K.T., Chen, B., Lin, H.-H., Fang, E., Wang, M., \& Wen, J.Y.-C. 2012. Application of the Living Lab Concept: Empirical Validation in Taiwan's Minsheng Community. International Journal of Automation and Smart Technology, 2(3): 209-229. http://dx.doi.org/10.5875/ausmt.v2i3.135

Huizingh, E. 2011. Open Innovation: State of the Art and Future Perspectives. Technovation, 31: 2-9.

http://dx.doi.org/10.1016/j.technovation.2010.10.002

Kang, S.-C. 2012. Initiation of the Suan-Lien Living Lab - A Living Lab with an Elderly Welfare Focus. International Journal of Automation and Smart Technology, 2(3): 189-199. http://dx.doi.org/10.5875/ausmt.v2i3.132

Katzy, B. 2012. Designing Viable Business Models for Living Labs. Technology Innovation Management Review, 2(9): 19-24. http://timreview.ca/article/604

Katzy, B. G., Baltes, G. H., \& Gard, J. 2012. Concurrent Process Coordination of New Product Development by Living Labs - An Exploratory Case Study. International Journal of Product Development, 17(1/2): 23-42. http://dx.doi.org/10.1504/IJPD.2012.051156 


\title{
The Grey Areas Between Open and Closed in Innovation Networks
}

\author{
Seppo Leminen, Taija Turunen, and Mika Westerlund
}

Kviselius, N. Z., Andersson, P., Ozan, H., \& Edenius, M. 2012. Living Labs as Tools for Open Innovation. Communications \& Strategies, 74(2): 75-94.

Laursen, K., \& Salter, A. 2006. Open for Innovation the Role of Openness in Explaining Innovation Performance among UK Manufacturing Firms. Strategic Management Journal, 27: 131-150. http://dx.doi.org/10.1002/smj.507

Lay, P., \& Moore, G. 2009. The Key to Competitive Advantage in Today's Global Bazaar. In J. Word (Ed.), Business Network Transformation: 1-16. San Francisco: Jossey-Bass.

Lazer, D., \& Friedman, A. 2007. The Network Structure of Exploration and Exploitation. Administrative Science Quarterly, 52: 667-694. http://dx.doi.org/10.2189/asqu.52.4.667

Leminen. S. 2015. Living Labs as Open Innovation NetworksNetworks, Roles and Innovation Outcomes. Doctoral dissertation.Helsinki, Finland: Aalto University.

Leminen, S., Nyström, A.-G., \& Westerlund, M. 2015. A Typology of Creative Consumers in Living Labs. Journal of Engineering and Technology Management, 37: 6-20.

http://dx.doi.org/10.1016/j.jengtecman.2015.08.008

Leminen, S., \& Westerlund, M. 2013. Incremental and Radical Service Innovation in Living Labs. In B. Christiansen, S. Yildiz, \& E. Yildiz (Eds.), Transcultural Marketing for Incremental \& Radical Innovation: 281-295. Hershey, Pennsylvania: Information Science Reference.

Leminen, S., \& Westerlund, M. 2012. Towards Innovation in Living Labs Network. International Journal of Product Development, 17(1/2): 43-59.

http://dx.doi.org/10.1504/IJPD.2012.051161

Leminen, S., \& Westerlund, M. 2011. On Becoming a User-Driven Firm: Slow-Cooked for Extra Goodness? Paper presented at the 2011 World Conference on Mass Customization, Personalization, and Co-Creation (MCPC): Bridging Mass Customization \& Open Innovation, San Francisco, USA, November 15-19, 2011.

Leminen, S., Westerlund, M., \& Nyström, A.-G. 2012. Living Labs as Open-Innovation Networks. Technology Innovation Management Review, 2(9): 6-11.

http://timreview.ca/article/602

Leminen, S., Westerlund, M., \& Nyström, A.-G. 2014. On Becoming Creative Consumers - User Roles in Living Labs Networks. International Journal of Technology Marketing, 9(1): 33-52. http://dx.doi.org/10.1504/IJTMKT.2014.058082

Lichtenthaler, U. 2010. Intellectual Property and Open Innovation: An Empirical Analysis. International Journal of Technology Management, 52(3/4): 372-391.

http://dx.doi.org/10.1504/IJTM.2010.035981

Lin, W.-Y., Lin, C.-T., Wang, Y.-H., \& Chen, R.-T. 2012. The Transformation of Users in Living Lab Construction: The Case of Eco-City Living Lab. International Journal of Automation and Smart Technology, 2(3): 231-240.

http://dx.doi.org/10.5875/ausmt.v2i3.140

Mulder, I., Velthausz, D., \& Kriens, M. 2008. The Living Labs Harmonization Cube: Communicating Living Lab's Essentials. The Electronic Journal for Virtual Organizations and Networks, 10: 1-14.

Neuendorf, K. A. 2002. The Content Analysis Guidebook. Thousand Oaks, CA: Sage.

www.timreview.ca
Nyström, A.-G., Leminen, S., Westerlund, M., \& Kortelainen, M. 2014. Actor Roles and Role Patterns Influencing Innovation in Living Labs. Industrial Marketing Management, 43(3): 483-495. http://dx.doi.org/10.1016/j.indmarman.2013.12.016

Pisano, G. P., \& Verganti, R. 2008. Which Kind of Collaboration Is Right for You? Harvard Business Review, 86(12): 80-86.

Rajala, R., Westerlund, M., \& Möller, K. 2012. Strategic Flexibility in Open Innovation - Designing Business Models for Open Source Software. European Journal of Marketing, 46(10): 1368-1388. http://dx.doi.org/10.1108/03090561211248071

Roberts, C. W. (Ed.) 1997. Text Analysis for the Social Sciences: Methods for Drawing Statistical Inferences from Texts and Transcripts. Mahwah, NJ: Lawrence Erlbaum.

Ryan, R., \& Deci, E. 2000. Intrinsic and Extrinsic Motivations: Classic Definitions and New Directions. Contemporary Educational Psychology, 25: 54-67. http://dx.doi.org/10.1006/ceps.1999.1020

Schweisfurth, T., Raasch, C., \& Herstatt, C. 2011. Free Revealing in Open Innovation: A Comparison of Different Models and Their Benefits for Companies. International Journal of Product Development, 13(2): 95-118.

Sjödin, D. R., Eriksson, P.-E., \& Frishammar, J. 2011. Open Innovation in Process Industries: A Lifecycle Perspective on Development of Process Equipment. International Journal of Technology Management, 56(2/3/4): 225-240.

http://dx.doi.org/10.1504/IJTM.2011.042984

Ståhlbröst, A., \& Bergvall-Kåreborn, B. 2011. Exploring Users Motivation in Innovation Communities. International Journal of Entrepreneurship and Innovation Management, 14(4): 298-314. http://dx.doi.org/10.1504/IJEIM.2011.043051

van der Walt, J., \& Buitendag, A. 2009. Community Living Lab as a Collaborative Innovation Environment. Issues in Informing Science and Information Technology, 6: 421-436.

von Hippel, E. 2001. Innovation by User Communities: Learning from Open-Source Software. MIT Sloan Management Review, 42(4): 82-86.

von Hippel, E. 2007. Horizontal Innovation Networks: By and for Users. Industrial and Corporate Change, 16: 293-315. http://dx.doi.org/10.1093/icc/dtm005

de Vries, E. J. 2006. Innovation in Services in Networks of Organizations and in the Distribution of Services. Research Policy, 35: 1037-1051. http://dx.doi.org/10.1016/j.respol.2006.05.006

Westerlund, M., \& Leminen, S. 2011. Managing the Challenges of Becoming an Open Innovation Company: Experiences from Living Labs. Technology Innovation Management Review, 1(1): 19-25. http://timreview.ca/article/489

Zaltman, G. 2003. How Customers Think: Essential Insights into the Mind of the Markets. Boston: Harvard Business School Press.

Yin, R. K. 2009. Case Study Research: Design and Methods. Thousand Oaks, CA: Sage.

Citation: Leminen, S., Turunen, T., \& Westerlund, M. 2015. The Grey Areas Between Open and Closed in Innovation Networks. Technology Innovation Management Review, 5(12): 6-18. http://timreview.ca/article/948

Keywords: innovation, innovation network, living lab, openness, closedness, open innovation 